\title{
VITAMINS AND SPORT
}

\author{
B. VAN DAM
}

Institute of sports medicine of the RWTH Aachen, Roermonderstraße 7-9, D-5100 Aachen, Germany

\section{INTRODUCTION}

For almost a year discussions about the pros and cons of anabolic steroids, the efficiency of the doping control, even a possible withdrawal of some kinds of sports from international competitions, have become a central theme of the sporting-world. Eventually the main committee of the Deutschen Sportbund in the "Grundsatzerklärung für den Spitzensport" in June, 1977 put a temporary end to these discussions for German competitive sport. In this declaration equality of opportunity and human welfare are emphasised. The results were the condemnation of doping, including anabolic steroids, as well as the rôle of sports medical care, to observe, to cure or to secure the health of the athlete wherever it is endangered.
\end{abstract}

\begin{abstract}
In a double blind test on 40 men and women high performance fencers the influence of a multivitamin-electrolyte- $\stackrel{\vec{一}}{\vec{A}}$ preparation on reaction time, hit-frequency and neuromuscular irritability was determined.

Evidence of $B_{1}, B_{2}$ and $B_{6}$-deficiencies up to $70 \%$ were found. After application of the preparation an increase of $\frac{0}{\infty}$ performance of $3 \%$ could be observed. The tests were carried out by means of coenzymatic activation of the respective? vitamins in the haemolysate of erythrocytes. The results are explained by the role of the vitamins in the human $\vec{N}$ organism and by the special conditions under which endurance athletes have to perform: high turn-over rate of the ? energy metabolism, an increase of the body core temperature and thus increased sweat loss, factors leading to $f$ deficiencies of the water soluble B-vitamins.
\end{abstract}

In recent publications it has been pointed out that "to be healthy" in the context of sports medicine investigation does not necessarily mean that the high score in fitness tests will not harm the organism, or that the athlete is, in a physiological sense, prepared optimally for the coming performance. Ergonomically, sport is labour, the caloric needs of which have to be covered by nutriment, and the calorie intake, as well as the composition of the main ingredients carbohydrates, fats, and proteins, is relatively easy to meet. Investigations of men and women athletes in competition indicated some considerable deviations from the optimum regarding electrolytes, minerals, and vitamins Haralambie, van Dam (1977), van Dam, Haralambie (1977). Though these investigations have been conducted entirely on men and women fencers, common physiological issues underlie the results, which allow an interpretation into other events besides fencing.

\section{SUBJECTS AND METHODS}

On 40 men and women fencers of the Bundesleistungszentrum Tauberbischofsheim (GFR) a series of doubleblind investigations on thiamine $\left(B_{1}\right)$, riboflavin $\left(B_{2}\right)$, 良 and pyridoxal $\left(B_{6}\right)$ was conducted in spring 1977 . These vitamins, together with other blood chemical parameters as well as neuromuscular irritability, hit-frequency and $\frac{\otimes}{\otimes}$ reaction time after optical stimulation have been determined. In this study 20 athletes received a granulated multi-vitamin electrolyte preparation "Beneroc" (Hoffman \& La Roche Company, Basel)*, the remaining 20 athletes a placebo. After application of $10 \mathrm{~g}$ granulate twice daily for 21 days the saturation of vitamins $B_{1}, \frac{0}{0}$ $B_{2}$, and $B_{6}$ and the above neuromuscular tests were $\exists$ again determined.

Seven women and 33 men fencers took part in this investigation, all belonging to the German national team $ᄋ$ or the best of their respective age classes. Among them were 7 Olympic medal winners (gold or silver) of 1976 을 and 2 finalists of the junior world championship 1977 in $V$ ienna. The women fencers were aged $18.3 \pm 3.0$ years, the men aged $18.9 \pm 3.5$ years. All the athletes investi- N gated belonged to the boarding school of the Bundesleis- N tungszentrum, which guaranteed that:

- All athletes carried out the same training in regard to power, velocity, and endurance,

- Regularity of training was controlled,

- A controlled diet was prepared for all the athletes.

"Contents: Ca $250 \mathrm{mg}, \mathrm{Mg} 170 \mathrm{mg}, \mathrm{K} 100 \mathrm{mg}$, phosphate $1080 \mathrm{mg}$, vit. $B_{1} 10 \mathrm{mg}$, vit. $B_{2} 15 \mathrm{mg}$, vit. $B_{6} 25 \mathrm{mg}$, niacinamide $20 \mathrm{mg}$, pantothenate $20 \mathrm{mg}$, vit. C $500 \mathrm{mg}$, vit. $E$ $50 \mathrm{mg}$, excip. ad $10.000 \mathrm{mg}$ (of which sucrose $3500 \mathrm{mg}$ ). 


\section{ANALYTICAL TECHNIQUE}

$5 \mathrm{ml}$ of blood were taken from the ante cubilal vein of the athletes, avoiding stasis, while they were at rest in the morning, after only a light breakfast. The samples were mixed with anticoagulant (50 $\mu \mathrm{I} \mathrm{Na-citrate} \mathrm{and} 6 \mathrm{mg}$ EDTA) and centrifuged after $\mathbf{4 0 ~} \mathrm{min}$. After removing plasma and buffycoat, the erythrocytes were washed twice with $0.9 \% \mathrm{NaCl}$ solution and haemolysed in distilled water by freezing-thawing.

Haemoglobin and the vitamin saturation for $B_{1}, B_{2}$, and $B_{6}$ were determined in haemolysate as follows:

1. Haemoglobin, by the cyanhaemoglobin assay of Richterich, 1971.

2. the vitamin $B_{1}$-saturation of the erythrocytes by measuring the transketolase activity with and without activation through thiaminpyrophoshate (Vo Khactu et al, 1974).

3. the vitamin $B_{2}$-saturation with the NADP-glutathione reductase reaction with and without activation through flavinadenine-dinucleotide (Glatzle et al, 1970; Haralambie, 1976).

4. the vitamin $B_{6}$-saturation with the help of aspartate-aminotransferase-assay (AST) with and without activation through pyridoxal-phosphate (Bayoumi and Rosalki, 1976).

Determinations of the vitamin saturations were made at body temperature, $37^{\circ} \mathrm{C}$. The results were calculated in international units $(\mathrm{U} / \mathrm{mmol} \mathrm{Hb})$. The activation coefficients

$$
A C=\frac{\text { activity with added coenzyme }}{\text { directly measured activity }}
$$

were determined and utilised by the following criterions:

$$
\begin{array}{ll}
\text { transketolase: } & A C \geqslant 1.25: \text { vitamin } B_{1} \text { deficiency } \\
\text { glutathione reductase: } & A C \geqslant 1.25: \text { vitamin } B_{2} \text { shortage } \\
\text { AST: } & A C \geqslant 1.90: \text { vitamin } B_{6} \text { deficiency }
\end{array}
$$

The neuromuscular irritability was measured at the flex. digit. sublimis with the constant-current stimulator Neuroton 626 (Siemens) for the 30, 10, 3, 1, 0.5, 0.3, and $0.1 \mathrm{sec}$ stimulation times before and after a twohour training load. Hit-frequency and reaction time were measured with the Messemer-Allstar apparatus before and after load.

\section{RESULTS}

The preliminary investigations of the double blind test produced activation coefficients, which were very similar to the values found in women fencers by Haralambie and van Dam (1977):

$$
\begin{aligned}
& B_{1}: 1.51 \pm 0.23 \\
& B_{2}: 1.26 \pm 0.09 \\
& B_{6}: 2.12 \pm 0.35
\end{aligned}
$$

Table I shows the specific significant decreases $(p<$ 0.001) of the hypovitaminoses for the group which received vitamins. On the other hand, the activation coefficients of the placebo group showed only a small, non-significant change. Figure 1 shows the alterations of hit-frequency before and after load with the specific
TABLE I

$\begin{array}{llll} & & \text { II } & \text { Sign. (I to II) } \\ B_{1} & 1.48 \pm 0.24 & 1.25 \pm 0.24 & p<0.001 \\ B_{2} & 1.24 \pm 0.05 & 1.06 \pm 0.08 & p<0.001 \\ B_{6} & 2.07 \pm 0.39 & 1.90 \pm 0.38 & p<0.001 \\ \bar{x} \pm \text { s.d; } N=19 ; & & I=1 . \text { Investigation } \\ & & \text { II }=2 \text {. Investigation (after Vit.) }\end{array}$

groups. Normally there are less hits after a 2 hour training. Although the group which received the preparation showed obviously worse results prior to this than the placebo group, they could catch up after application of "Beneroc".

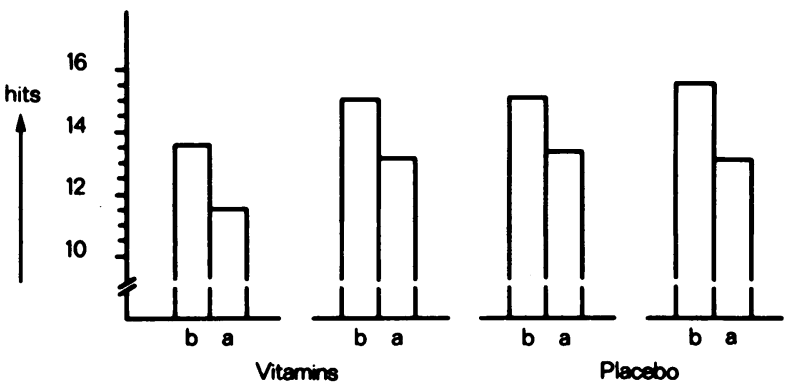

Figure 1. Fencers' hit-frequency of the vitamin treated group before (b) and after (a) a two hour training session during the investigation before the beginning of the double-blind-study (1st pair of columns) and after the application of a multi-vitaminagent (2nd pair of columns); the same for the placebo group.

One can notice an increase of the reaction time parallel to the decrease of hit-frequency after exercise. This phenomenon was less distinctive in the group which received vitamins. The absolute values are:

\section{TABLE II}

Before training
sec
100

After
sec
100

$\Delta$ sec $\Delta \%$

Placebo $\quad 49.75 \pm 5.05$

Vitamins $49.95 \pm 5.11$

$54.50 \pm 5.48$

4.75

9.55

$53.45 \pm 4.91 \quad 3.50$

7.00

$\bar{x} \pm$ s.d.; $N=19$

For the flexor digitorum sublimis muscle, which consists mainly of phasic fibres, the neuromuscular irritability changed inessentially for the long stimulation times. The measured mean value for the stimulation time of $0.1 \mathrm{msec}$ however is significantly lower $(\mathrm{p}<0.001)$ 
for the experimental group before and after load than for the placebo group (Fig. 2), whereas the increase of the current threshold needed for a minimal twitch in both groups $(\Delta \mathrm{mA})$ is equal (Table III).

\section{TABLE III}

\begin{tabular}{rlll} 
& \multicolumn{1}{c}{ Placebo } & Vitamins & Sign. \\
I & $6.88 \pm 2.16 \mathrm{~mA}$ & $6.84 \pm 2.42 \mathrm{~mA}$ & n.s. \\
II b & $7.17 \pm 2.24 \mathrm{~mA}$ & $5.73 \pm 1.93 \mathrm{~mA}$ & $p<0.001$ \\
$\Delta \mathrm{mA}$ b/a & $0.90 \pm 1.72 \mathrm{~mA}$ & $1.05 \pm 1.64 \mathrm{~mA}$ & n.s. \\
II a & $8.07 \pm 2.02 \mathrm{~mA}$ & $6.78 \pm 1.87 \mathrm{~mA}$ & $p<0.001$
\end{tabular}

$\bar{x} \pm$ s.d.; $\quad I=1$. Investigation

II = 2. Investigation (after Vit.)

$a=$ after load
$b=$ before load
$N=19$ (both groups)

\section{RÓLE OF THE VITAMINS $B_{1}, B_{2}$, AND $B_{6}$ IN THE HUMAN ORGANISM}

It is necessary to mention some characteristics of the vitamins $B_{1}, B_{2}$, and $B_{6}$ in order to answer the question to the possible importance of the relatively high percentage of cases with deficiency.

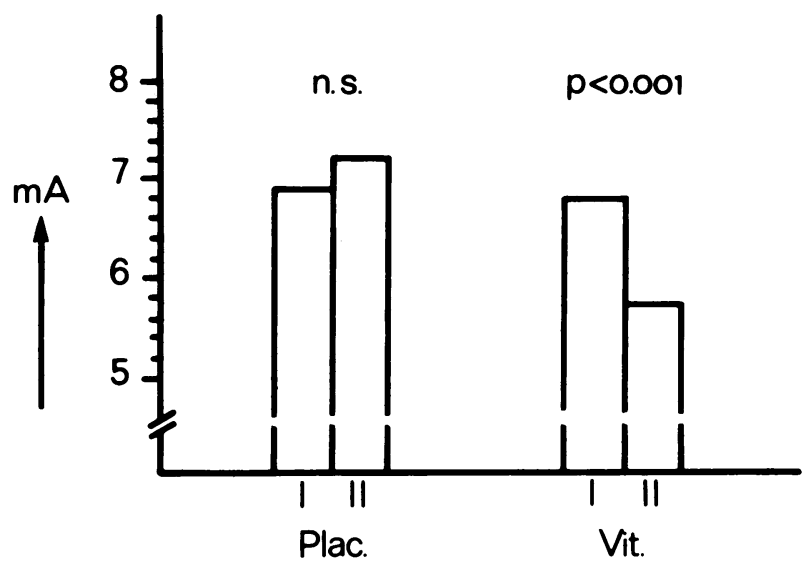

Figure 2. Neuromuscular irritability for stimulation time of $0.1 \mathrm{msec}$. The mean values at rest do not differ significantly between the 1st and 2nd investigation of the placebo group. With the vitamin-treated group they differ significantly (p $<$ 0.001).

Figure 3 shows the essential, simplified locations of action of $B_{1}, B_{2}$, and $B_{6}$ in the intermediate metabolism, in the citrate cycle, in the respiratory chain, and in nerve impulse conduction.

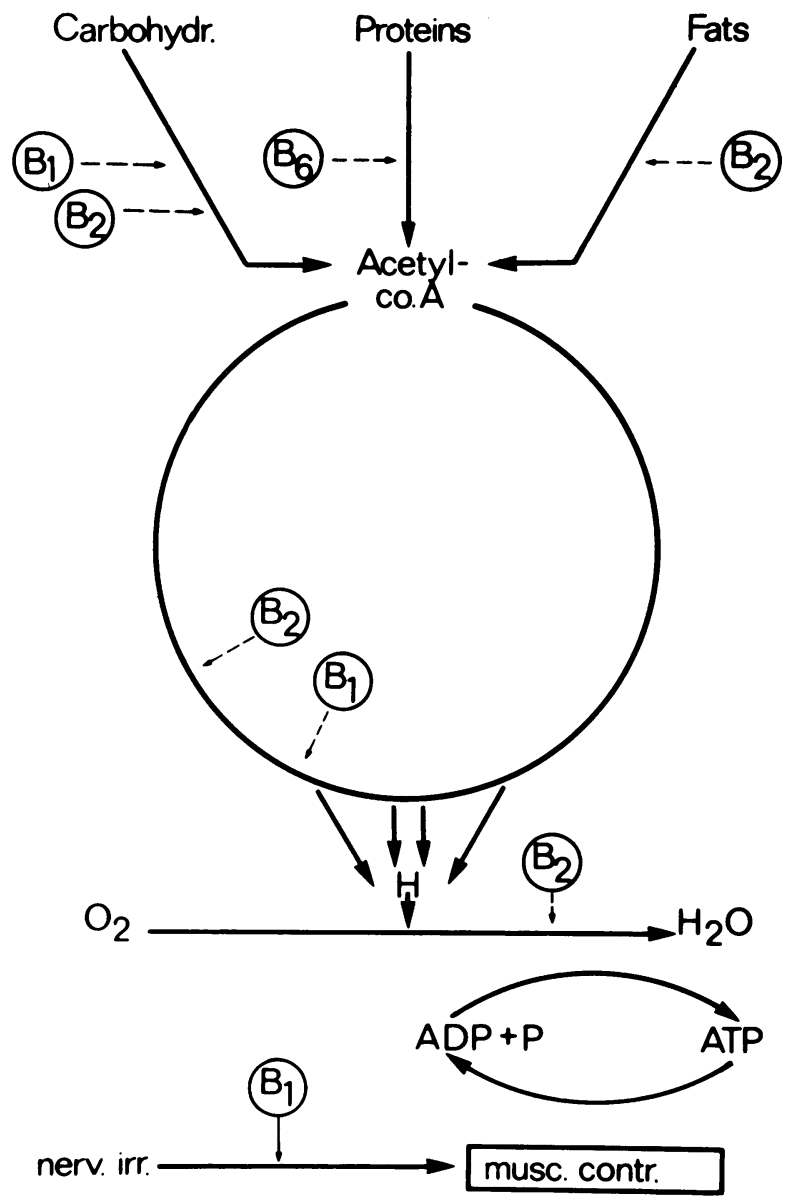

Figure 3. The most important locations of effect of the vitamins $B_{1}, B_{2}$ and $B_{6}$ in the intermediate metabolism, in the Krebs cycle, in the respiratory chain and with nerve impulse conduction.

Vitamin $B_{1}$ (thiamine), is involved as the coenzyme cocarboxylase in the oxidative decarboxylation of $I$ several carbonic acids. Through this process activated acetic acid (acetylcoenzyme A), is produced, which on $\tilde{\sigma}^{\circ}$ one hand is the first step in the oxidative metabolism, and on the other is the starting material for the lipid synthesis. An increased supply of carbohydrates implies an increased $B_{1}$-need. Severe symptoms of deficiency (beriberi) do not appear with balanced nutriment, but a syndrome of neurastenical complaints, of weariness and lack of appetite is the consequence of a mild $B_{1}$-hypovitaminosis.

$B_{2}$ (riboflavin) functions, among other forms, as $F A D$, a part of many hydrogen transferring enzymes (respiratory chain). Generally speaking FAD participates in the metabolism of carbohydrates, fatty and amino 
acids, by supplying hydrogen to the specific dehydrogenases for the oxidation. The $\mathbf{B}_{\mathbf{2}}$-need mainly increases with fatty nutrition, because of the participation of FAD in the catabolism of fatty acids. Deficiency of riboflavin moreover implies an impaired amino acid utilisation: thus it leads to a reduced protein synthesis.

Deficiencies are non-specific, and appear mainly on the dermatological and neurological spheres. Weariness and apathy accompany the deficit.

$B_{6}$ (pyridoxal or other forms) is concerned with the metabolism of amino acids. It illustrates a connection between metabolism of carbohydrates, fatty acids, and of energy, e.g. as a coenzyme of transaminases.

Pyridoxalphosphate assists in the first step of haemaglobin-synthesis and is necessary for the transport of amino acids and magnesium into the cell.

An increase of proteins intake always implies an increased $B_{6}$-need, the latent deficit is evident in a vague syndrome, in which tiredness, lack of appetite, dermatological and neurological infections dominate.

\section{DISCUSSION}

From the facts mentioned above it is obvious that a deficiency of vitamins is above all a disproportion between the supply of vitamins and the main parts of nutrition: carbohydrates, fats, and proteins. Therefore we cannot expect a raise of performance by giving vitamins beyond the physiological need.

Sport participation, however, needs a multiplication of the recommended daily allowances, especially of the B-vitamins, because:

1. the increase of the athlete's muscular load goes along with an increase of metabolism, dependent on duration and intensity of performance. Jakovlev figured out a marathon-walker's caloric need as $0.3 \mathrm{kcal} / \mathrm{sec}$, yet that of a heavy manual worker as only $0.07 \mathrm{kcal} / \mathrm{sec}$ : a proportion of $4: 1$ ! Thus an endurance athlete's calorie consumption can amount to up to $10.000 \mathrm{kcal} /$ day (Nöcker, 1976; Nöcker, 1974).

2. Processes of metabolism, as is well known, are dependent on temperature. Physical performance is linked to a rise in temperature, often more than $2^{\circ} \mathrm{C}$. We found that the body core temperature of fencers had increased about $2.5^{\circ} \mathrm{C}$ after several hours of training.

3. Water solubility of the B-vitamins brings about increased excretion through the kidneys, and by perspiration. Nöcker (1974) states that water loss is approximately $1 \mathrm{~kg} /$ day for fencers. Our measurements at qualification- and world-championship tournaments showed a decrease in body-weight up to $8 \mathrm{~kg}$ in two days, mainly through loss of water due to the prescribed protective clothing.

These factors, despite balanced nutrition, as a consequence of the magnitude of high-performance training, lead to a deficiency of these B-vitamins. In 1960, Prokop (reported in 1969) discovered the positive effect of vitamin preparations on the athlete's general state of health. Since then, several papers have been published which discuss single motor phenomena in connection with B-vitamins: neural conduction velocity with $B_{1}$ and $B_{6}$ (Popescu, Popescu et al, 1976), as well as neuromuscular irritability and $B_{2}$ (Haralambie, 1976; Haralambie, Keul et al, 1975). The effect of vitamin-Bcomplexes on circulation and metabolism (Keul, Haralambie et al, 1974), on hypovitaminoses within clinical range (Hoorn, Flinkweert et al, 1975), and on the glycolysis in animals are described as well (Brin, Shohet et al, 1958).
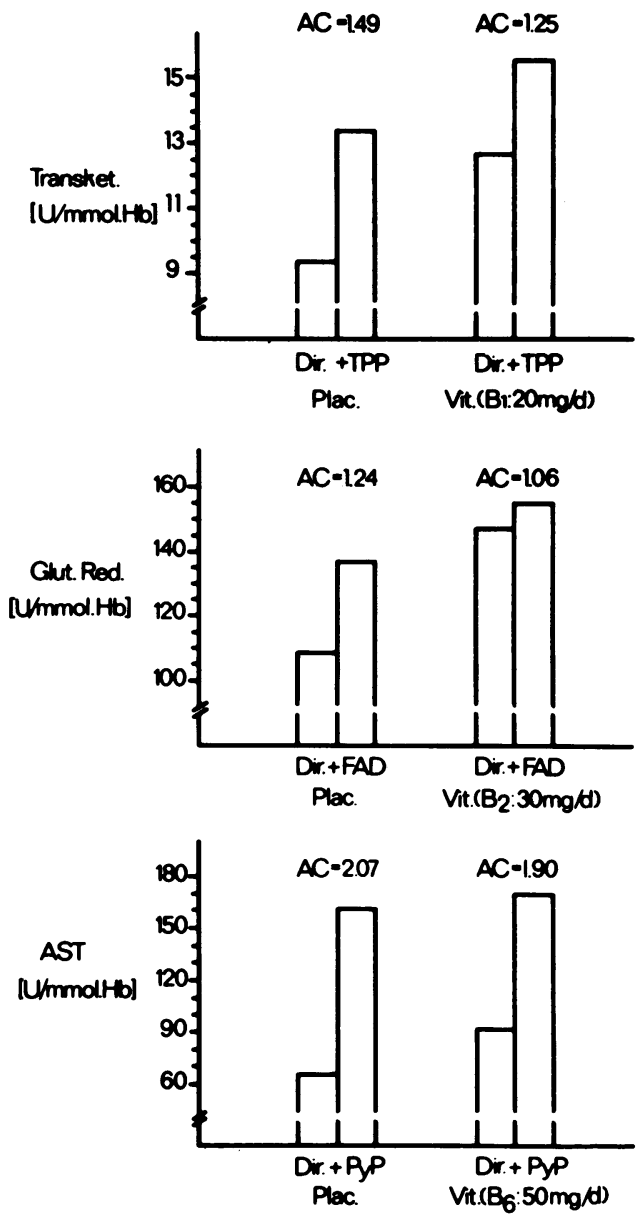

Figure 4. Comparison of the results of the vitamin saturation tests of the agent group and placebo group before and after activation by the specific coenzyme. 
This study on the saturation of the body with the three B-vitamins demonstrates the need of a better supply of the metabolism with those vitamins.

Although "Beneroc", the preparation we used, is a multi-vitamin electrolyte granulate, the improvement in our specific neuromuscular tests can be attributed mainly to the effect of the vitamins because of their role in the metabolism. The minor rise in the reaction time of the treated groups after the training may be seen, surely, as a result of the effect of thiamine on nervous conduction velocity and glycolysis. The more favourable reaction of the irritability of the phasic muscle fibres, may be due to $B_{1}$ and $B_{2}$. Haralambie assumes that $B_{2}$ influences positively not only the oxidative processes, but also glycolysis, by control of free thiol groups by glutathione reductase (Haralambie, 1976).

Figure 4 shows that an increased need for $B_{1}$ and $B_{2}$ invoked by a hard daily training could be covered by $20 \mathrm{gr}$ of the granulate. The mean value of the activation coefficients of the transketolase after TPP activation for the placebo group is about the same as the mean value without TPP activation for the treated group. The glutathione reductase, after activation with FAD, shows similar results compared with the vitamins without activation. There is, however, a discrepancy with $\mathrm{B}_{6}$ : the activation with pyridoxalphosphate gave much higher AST-results in the placebo group than in the experimental group without activation; in the latter group we found seven subjects with $B_{6}$-hypovitaminoses among 19. The quantity of $B_{6}$ required is possibly higher than the quantity in the granulate, suggested by the correlation between a rise in the serum urea after physical load and $\mathrm{B}_{6}$-deficiency (Haralambie). Probably the raised urea level found in high performance athletes are less a sign of lack of adaptation to performance in the organism that a sign of the consequence of a $\mathrm{B}_{6}$. deficiency.

Substitution of used vitamins does not represent, of course, a pharmacologiral increase of performance nor is it doping. Medical care has to aim for securing or reestablishing health where it is restricted (Hauptausschuss des Deutschen Sportbundes, 1977).

Even dietetically composed nutrition is not always sufficient to cover vitamin needs which can increase a great deal in active athletes.

\section{REFERENCES}

Bayoumi, R. A. and Rosalki, S. B. 1976. Evaluation of methods of coenzyme activation of erythrocyte enzymes for detection of deficiency of vitamins $B_{1}, B_{2}$ and $B_{6}$. Clin. Chem. 22: 327-335.

Brin, M., Shohet, S. and Davidson, C. S. 1958. The effect of thiamine deficiency on the glucose oxidative pathway of rat erythrocytes. J.Biol.Chem. 230: 319.

Glatzle, D., Körner, W. F., Christeller, S. and Wiss, O. 1970. Method for detection of biochemical riboflavin deficiency ... Int.Z. Vitaminforschg. 40: 166.

Haralambie, G. 1976. Vitamin $B_{2}$ status in athletes and the influence of riboflavin administration on neuromuscular irritability. Nutr.metabol. 20: 1-8.

Haralambie, G. and van Dam, B. 1977. Untersuchungen über den Vitamin-Elektrolytstatus bei Spitzenfechterinnen. Leistungssport 3: 214-219.

Haralambie, G., Keul, J., Baumgartner, A., Winker, K. H. and Bauer, G. 1975. Die Wirkung eines MultivitaminElektrolytpräparates auf Elektrodermalreflex und neuromuskuläre Erregbarkeit bei langwährender Körperarbeit. Schweiz.Z.Sportmed. 23: 113-128.

Hauptaussschuss des Deutschen Sportbundes. 1977. Grundsatzerklärung für den Spitzensport. Baden-Baden, June 1977.

Hoorn, R., Flinkweert, J. and Westerink, D. 1975. Vitamin $B_{1}, B_{2}$ and $B_{6}$ deficiencies in geriatric patients... Clin.Chim. Acta 61: 151-162.

Keul, J., Haralambie, G., Winker, K. H., Baumgartner, A. and Bauer, G. 1974. Die Wirkung eines MultivitaminElektrolytgranulats auf Kreislauf und Stoffwechsel bei langwährender Körperarbeit. Schweiz.Z.Sportmed. 22: 169.

Nöcker, J. 1976. Physiologie der Leibesübungen, Enkeverlag, Stuttgart. 
Nöcker, J. 1974. Die Ernährung des Sportlers, Hofmann Verlag, Schorndorf.

Popescu, F., Popescu, V. and Rust, M. 1976. Medikamentöse Beeinflussung der Nervenleitgeschwindigkeit. Ärztl.Praxis 28: 836 .

Prokop, L. 1969. Multivitamine bei Spitzenathleten. Ärztl.Praxis 21: 3005.

Richterich, R. 1971. Klinische Chemie, Verlag S. Karger, Basel.

Van Dam, B. and Haralambie, G. 1977. Die Änderungen einiger biochemischer Parameter durch die sportartspezifischen Belastungen im Fechtsport. Leistungssport 4: 285-292.

Vo Khactu, K., Clayburgh, R. and Sandstead, H. 1974. An improved NADH-dependent transketolase assay for assessing thiamine nutriture. J. Lab. Clin.Med. 83: 983-989. 